\title{
PERAN ORANGTUA SEBAGAI PENDIDIK DAN PEMBENTUK KARAKTER SPIRITUALITAS REMAJA
}

\author{
Christa Siahaan \\ christabarita@gmail.com \\ Djoys Anneke Rantung \\ Universitas Kristen Indonesia \\ Djoys.anneke@gmail.com
}

\begin{abstract}
Abstrak
Artikel ini berisi pembahasan tentang peran orangtua sebagai pendidik dan pembentuk karakter spiritualitas remaja dalam pandangan Alkitab dan secara psikologis. Pendidikan karakter spiritualitas remaja merupakan satu dari sekian banyak tujuan pembelajaran PAK. Guru yang berperan dalam pengajaran PAK tidak hanya yang ada dalam sekolah formal saja. Dalam sekolah informal ada guru yang paling dekat dengan naradidiknya bahkan tinggal dalam satu rumah yaitu orangtua. Sebagai guru PAK orangtua berperan dalam membentuk karakter spiritualitas remaja. Orangtua dikatakan sebagai guru pertama dan utama dalam mengajarkan firman Tuhan kepada remaja. Pengajaran yang diberikan hendaknya dapat membentuk suatu kepribadian yang khas dari remaja. Inilah yang disebut sebagai pembentukan karakter spiritualitas.
\end{abstract}

Kata Kunci : Peran Orangtua, Pendidik, Karakter, Spiritualitas, Remaja

\section{A. Pendahuluan}

Perkembangan karakter spirituallitas remaja akan bertumbuh dengan baik bila ada campur tangan orang lain di luar dirinya. Orang lain yang dimaksud adalah pembina spiritualnya seperti guru Pendidikan Agama Kristen (PAK), orangtua dan pendeta dari gerejanya masing-masing. Dalam tulisan ini akan dipaparkan berbagai pendapat tentang peran orangtua, pembentukan karakter spiritual, dan tentang remaja. Setiap orangtua bertanggung jawab atas generasinya masing-masing. Orangtua yang takut akan Tuhan harus memiliki prinsip hidup bahwa keturunannya haruslah menjadi manusia yang memiliki karakter yang mulia dan terpuji. Anak remaja masih labil dan belum menemukan jati diri yang sebenarnya. Karena itu butuh bantuan dari luar dirinya agar mereka memiliki konsep diri yang jelas dalam menuju kedewasaan secara jasmani dan rohani dan inilah yang disebut dengan proses pembentukan karakter spiritualitas.

\section{B. Peran Orangtua dalam Pandangan Alkitab dan Psikologi}

Keluarga adalah salah satu dari tiga lembaga di bumi ini yang menjadi representasi Kerajaan Allah dan menjadi tempat yang paling aman dan nyaman bagi semua anggota keluarga. Keluarga sudah ada sejak zaman purba kala, sejak manusia diciptakan oleh Allah dan di tempatkan di Taman Eden. Keluarga adalah rancangan 
Allah bagi manusia, Allah membentuk keluarga dan memberkatinya supaya mereka melahirkan keturunan untuk memenuhi bumi (Kej. 1:26-28). Keluarga menjadi tempat untuk melahirkan benih Ilahi (Mal. 2:15) supaya melahirkan generasi yang kudus. Keluarga menjadi objek perhatian Tuhan dalam melanjutkan rencana-Nya. Keluarga sebagai manifestasi Kerajaan Allah ditandai dengan hadirnya damai sejahtera dan suasana surgawi. Suami menunjukkan kebapaan Allah dan istri mencitrakan kelembutan dan kesetiaan Allah. Hanya kehidupan doa yang dapat menciptakan hubungan yang intim dengan Allah dan kehidupan rohani menjadi bertumbuh. ${ }^{1}$ Suami dan istri yang disebut juga ayah dan ibu, akan melahirkan anak-anaknya sesuai dengan perintah Tuhan dalam Perjanjian Lama. Merekalah (ayah dan ibu) yang disebut sebagai orangtua. Orangtua sebagai perpanjangan tangan Tuhan di dunia ini untuk membimbing dan melindungi setiap anak. Orangtua sebagai guru utama dan pertama bagi anaknya dalam menciptakan anak yang taat akan Tuhan, yang mengerti dan menjalankan maksud-Nya serta menjauhi laranganNya.

Keluarga pertama mengalami kegagalan, karena mereka tidak taat kepada Allah. Karena ketidaktaatannya maka mereka diusir dari Taman Eden, dan mereka harus berjuang untuk memenuhi segala kebutuhan hidupnya. Kesusahan mulai datang, pembunuhan pun terjadi. Kakak membunuh adiknya (Kej. 4). Kedamaian dan ketenangan sudah tidak ada. Anggota keluarga pun menjadi ancaman. Setiap anggota keluarga seharusnya saling melindungi, namun yang terjadi adalah sebaliknya. Kejatuhan manusia kedalam dosa membuat manusia

\footnotetext{
${ }^{1}$ Sudiyono dan Ruth Purweni, Generasi Akhir Zaman yang Dirindukan Tuhan (Yogyakarta: Andi, 2017), 77-78.
}

cenderung untuk berbuat jahat. Perkembangan zaman terus meningkat, kejahatan pun terus bertambah. Setiap anggota keluarga butuh perlindungan, terlebih anak-anak dari keluarga tersebut. Anak dalam keluarga sangat rentan dengan kejahatan, karena itu anak perlu dilindungi dan diberikan pembekalan supaya mampu melindungi dirinya sendiri. Orangtua adalah orang pertama yang memperhatikan seluruh tingkah laku setiap anak dalam keluarga. Setiap orangtua hendaknya menyadari dan dapat memiliki pemahaman yang benar akan pentingnya peran mereka dalam membentuk karakter anaknya menuju kesempurnaan. Peran orangtua sangatlah dibutuhkan dalam memberikan pendidikan karakter spiritual anak dalam keluarga.

1. Peran Orangtua dalam Pandangan Alkitab

\section{a. Peran Orangtua dalam Perjanjian Lama}

Pengetahuan anak, kepribadian anak dan kerohanian anak tidak terjadi dengan sendirinya dan tidak diturunkan oleh orangtua, walaupun ada sifat bawaan. Hal lain yang mepengaruhinya adalah lingkungan di mana ia dibesarkan. Karena itu orangtua dan para pendidik perlu sekali memberikan masukan kepada anak dan membimbing mereka agar dapat bertumbuh menjadi anak yang berkenan kepada Allah. Anak yang berkenan di hadapan Allah adalah menunjukkan sikap hormat terhadap orangtua, menjalankan fungsinya dengan baik, sebagai pelajar akan belajar dengan baik, sebagai teman akan menjadi teman yang baik, dan bahkan mampu menjadi warga yang baik juga. Menurut kitab Ulangan pasal 6 Allah memerintahkan orangtua mengajari anak- 
anaknya untuk mengenal Tuhan dalam segala aspek kehidupan. Perintah itu disertai dengan cara pengajaran. Tuhan memerintahkan orangtua untuk mengajarkan secara berulang-ulang, di mana saja, kapan saja, dan dengan segenap kemampuan, termasuk menjadi teladan. ${ }^{2}$ Karena teladan yang diberikan orangtua jauh lebih keras berbicara dari seribu katakata. Kebiasaan yang dilakukan dalam suatu keluarga akan sangat memmengaruhi keadaan rohani seorang anak.

Dalam kehidupan Israel atau dalam tradisi Ibrani, setiap aspek kehidupan dijadikan sebagai isi pengajaran dalam mengasihi Tuhan. Pengajaran yang selalu dihubungkan dengan doa atau Syema dalam bahasa Ibrani, yang dilakukan pada malam dan pagi. Melalui hal itu anak akan belajar di dalam komunitas kehidupan dengan anak-anak lain di bawah pengawasan orangtuanya. Dari lingkungan sekitarnya anak akan mendapat pengaruh, baik dan buruk. Maka orangtua berperan untuk selalu menyertai mereka belajar langsung dari lingkungan sekitarnya. ${ }^{3}$ Tujuannya adalah supaya pengaruh baik dapat membangun kepribadian anak dan hal yang buruk tidak mempengaruhi kebiasaan baik itu. Anak dalam masa remajanya akan gampang diombang ambingkan pengaruh luar jika tidak mendapat bimbingan dari orangtua. Peran orangtua sangat penting untuk mampu mengarahkan mereka.

Hal lain yang mendasari orangtua memiliki peran penting dalam membina karakter spiritual anaknya adalah Mazmur 78, di mana hukum taurat diberikan-Nya untuk diperkenalkan oleh keturunan Yakub kepada anak-anak mereka. Artinya ketetapan-ketetapan Tuhan dijadikan dasar

\footnotetext{
${ }^{2}$ Ibid., 80.

${ }^{3}$ Susan S. Wiriadinata, Ardi Wiriadinata, dan John Sudarma, Mengasuh Anak Mengasihi Tuhan (Jakarta: Gramedia, 2018), 2.
}

pengajaran secara turun-temurun. Jadi yang mengajarkan segala ketetapan Tuhan haruslah orangtua bukan gereja atau pemerintah sebagai lembaga lain yang turut juga menjadi pengajar bagi anak. Maka dapat dikatakan bahwa sudah ada ketetapan dari bapa leluhur untuk mengajarkan ketetapan dan hukum Tuhan secara turun temurun dari orangtua kepada anak-anaknya, bukan kepada anak orang lain. ${ }^{4}$ Bukan dari orangtua yang lain tetapi dari orangtua si anak itu sendiri. Cara mengajarkanpun disebutkan yaitu secara turun-temurun. Maka setiap orangtua akan mengajarkan kepada anaknya dan setelah anak dari keluarga tersebut punya anak, maka ia pun harus mengajarkan kepada anaknya. Ketetapan Tuhan akan diajarkan secara turun-temurun. Pelaksanaan pengajaran tentang ketetapan Tuhan seperti siklus, tidak diam atau berhenti hanya pada satu keturunan. Akan selalu diajarkan turun-temurun dan orangtua yang berperan untuk mengajarkannya.

Kitab Amsal memerintahkan kepada para orangtua agar mendidik anaknya sejak dini. Bila anak sejak dini sudah diajari untuk mengenal Tuhan, maka sampai dewasa tidak akan meninggalkan Tuhan. Karena bagaimanapun, orang yang mengenal Tuhan yang hidup sesuai dengan ajaranNya, akan lebih beruntung. "Didiklah orang muda menurut jalan yang patut baginya, maka pada masa tuanyapun ia tidak akan menyimpang" (Amsal 22:6). ${ }^{5}$ Setiap orangtua menginginkan anaknya menjadi pribadi yang unggul dan hebat. Anak yang berguna, menjadi teladan dalam perkataan dan perbuatan. Hidup dengan teratur dan membahagiakan orangtua. Impian ini akan ditemukan dalam diri anak yang orangtuanya peduli

\footnotetext{
${ }^{4}$ Ibid., 3-4.

${ }^{5}$ Susan S. Wiriadinata., Op.Cit, 7.
} 
pada pendidikan karakter spiritualnya. Karena dengan melakukan kehendak-Nya sajalah orang percaya akan beruntung (bnd. Josua 1:8 yang mengatakan: "Janganlah engkau lupa memperkatakan kitab Taurat ini, tetapi renungkanlah itu siang dan malam, supaya engkau bertindak hati-hati sesuai dengan segala yang tertulis di dalamnya, sebab dengan demikian perjalananmu akan berhasil dan engkau akan beruntung").

Orangtua harus mengabdikan diri mereka untuk memberi didikan disiplin rohani kepada anak-anak mereka (bnd. ayat Ams. 22:15; 13:24; Ams. 19:18; 23:13-14; 29:17). Kata Ibrani untuk "mendidik" berarti "mengabdikan". Jadi, didikan Kristen bertujuan mengabdikan anak-anak kita kepada Allah dan kehendak-Nya. Hal ini akan tercapai apabila mereka jauh dari pengaruhpengaruh jahat dunia dan dengan mengajar mereka berperilaku saleh. Akar kata yang sama juga bisa berarti "memberi atau meningkatkan kegemaran akan"; orangtua harus mendorong anak-anak mereka agar mereka sendiri mencari Allah dan dengan demikian dapat menikmati pengalaman-pengalaman rohani yang takkan mereka lupakan. "Ia tidak akan menyimpang daripada jalan itu". Prinsip umumnya ialah bahwa seorang anak yang telah dididik dengan benar tidak akan menyimpang dari jalan saleh yang telah diajarkan orang-tuanya. Akan tetapi, hal ini bukan jaminan mutlak bahwa semua anak dari orang-tua yang takut akan Allah akan tetap setia kepada Allah dan firmanNya. Ketika hidup di tengah masyarakat jahat di mana banyak umat Allah sendiri tidak setia, maka anak-anak dari orang-tua beriman dapat terpengaruh untuk berbuat dosa dan menyerah kepada pencobaan (lih. Yeh. 14:14-20, di mana Allah berbicara

\footnotetext{
6 Alkitab Sabda, https://alkitab.sabda.org/bible. php?book=Ams\&chapter=22\#n5, diakses pada tanggal 11 Juli 2019, pukul 17:50 WIB.
}

tentang kemurtadan yang demikian besar sehingga bahkan orang benar seperti Nuh, Daniel, dan Ayub tidak dapat menyelamatkan anak mereka). ${ }^{6}$

Pendidikan penting untuk mempersiapkan masa depan. Pendidikan akan menjauhkan orang dari kebodohan (Ams. 22:15). Selain itu, pendidikan akan mengembangkan potensi yang terdapat di dalam diri seseorang. Pendidikan pada masa muda merupakan investasi yang tepat, yang akan memberikan manfaat besar di hari tua kelak (Ams. 22 : 6). Artinya pendidikan bukan hanya berguna untuk seketika waktu saja, melainkan di sepanjang hidup. Selain itu, pendidikan memang lebih baik diberikan ketika seseorang masih cukup muda, yakni ketika ia relatif lebih mudah berubah ke arah yang lebih baik. Maka sepanjang hidup akan dia jalani sesuai dengan didikan yang telah diterima. Didikan akan memampukan orang untuk memilih jalan bijak dan bukan jalan kefasikan. Kemampuan untuk memilih itulah yang akan menentukan kesuksesan hidup. Tentu saja prilaku seseorang akan jauh berbeda bila orang tidak diberikan pendidikan pada kesempatan yang paling baik di dalam hidupnya, yaitu pada masa mudanya. Ini mencakup masa kanak-kanak sampai mencapai taraf kematangan. Bila di dunia ini ada hal yang tidak bisa ditunda-tunda maka pendidikan anak adalah salah satunya. Namun perlu dipahami bahwa yang dimaksud dengan pendidikan bukan sekadar memberi anak makan, menyediakan pakaian dan ruang tidur yang nyaman! Bahkan membentak atau memasukkan anak ke sekolah Kristen pun bukan sebuah pendidikan! Pendidikan mencakup tindakan mengajar, menasehati, mendisiplin anak, dsb. Mendidik adalah sebuah upaya membentuk karakter hingga 
anak hidup takut akan Allah. Orangtua yang tidak mendidik anak berarti membiarkan mereka menjadi perusak dunia. Maka orangtua harus menyadari bahwa masa untuk mendidik anak begitu terbatas dan harus dimanfaatkan sebaikbaiknya. Apabila kesempatan emas itu bergulir begitu saja, tentu orangtua harus mempertanggungjawabkannya di hadapan Tuhan. $^{7}$

Menurut Susan, dalam Alkitab Perjanjian Lama ada beberapa nats yang menjadi dasar dalam membina karakter spiritualitas anaknya. Orangtua diharuskan untuk mengajar dan aktif dalam pengajaran mengenai firman Tuhan. Alkitab memerintahkan orangtua mengajarkan kehendak Tuhan kepada anaknya. Bukan hanya memberi perintah tetapi metode mengajarkan juga dicantumkan, misalnya, ${ }^{8}$ Orangtua harus mengajar dengan teladan (Keluaran 6:5-8; 31:12).

1) Orangtua harus mengomunikasikannya secara verbal (Kel. 6:7 tentang syema, Ul. 11:18-19).

2) Keluarga mendiskusikan secara informal apa yang terjadi sepanjang hari (U1. 6:20-25).

3) Orangtua dapat mengajar anak ketika anak bertanya (Kel. 12:26; 13:14; Ul. $6: 21)$.

4) Orangtua dapat menggunakan bahan ajar atau bahan visual sebagai contoh (U1. 6:9; 11:20).

5) Orangtua mengajarkan kepada mereka untuk berpartisipasi dengan merayakan kegiatan-kegiatan, hari raya sepanjang tahun (Ul. 16:16).

Dalam menyampaikan pengajarannya orangtua perlu mengetahui metode dan cara yang tepat dalam mengajarkan firman Tuhan. Salah satu cara pengajaran

7 Alkitab Sabda, https://alkitab.sabda.org/ commentary.php?book $=20 \&$ chapter $=22 \&$ verse $=8$, diakses pada tanggal 11 Juli 2019, pukul 18:10 WIB. yaitu dengan memberikan teladan melalui kehidupan sehari-hari. Metode pengajarannya dapat dilakukan dengan mendiskusikan firman tersebut.

\section{b. Peran Orangtua dalam Perjanjian Baru}

Orangtua diperintahkan oleh Allah untuk mendidik anaknya seperti yang tertulis dalam Efesus 6:4, "Dan kamu, bapa-bapa, janganlah bangkitkan amarah anak-anakmu, tetapi didiklah mereka di dalam ajaran dan nasihat Tuhan." Dengan demikian orangtua berperan untuk menjadi guru rohani bagi anak-anaknya. Sebelum orangtua menjadi pengajar terlebih dahulu mereka harus hidup beriman. Maka orangtua harus terlebih dahulu mempelajari firman Tuhan, "Usahakanlah supaya engkau layak di hadapan Allah sebagai seorang pekerja yang tidak usah malu, yang berterus terang memberitakan perkataan kebenaran itu" (2Tim. 2:15). Semua orang percaya bertanggung jawab dalam mengajarkan firman Tuhan termasuk di dalamnya mereka sebagai orangtua atau orang yang sudah dewasa. ${ }^{9}$ Orangtua mempunyai tanggung jawab dalam mengajarkan firman Tuhan dan peran mereka adalah sebagai pendidik.

Menurut Dennis Mccallum, mengatakan bahwa, Injil harus toleran terhadap budaya yang dimiliki oleh para remaja. Remaja dalam budaya tradisional menerima saja ritual yang mereka harus lalui dalam sistem keyakinan masyarakat desanya tanpa mempertanyakan apa-apa. Budaya orangtua dan budaya anak-anak mereka harus sama, supaya mereka tidak berada pada dunia yang berbeda. Tindakan ini harus menjadi strategi gereja agar tidak terjadi pergeseran budaya. Mengenai

\footnotetext{
${ }^{8}$ Susan S. Wiriadinata., Op.Cit, 4-5

${ }^{9}$ Sudiyono, Op.Cit., 328.
} 
orangtua menanamkan budaya kepada anaknya didukung oleh 1 Korintus $7: 17$ 18 mengatakan, "Selanjutnya hendaklah tiap-tiap orang tetap hidup seperti yang telah ditentukan Tuhan baginya dan dalam keadaan seperti waktu dipanggil Allah. Inilah ketetapan yang kuberikan kepada semua jemaat. Kalau seorang dipanggil dalam keadaan bersunat, janganlah ia berusaha meniadakan tanda-tanda sunat itu. Dan kalau seorang dipanggil dalam keadaan tidak bersunat, janganlah ia mau bersunat." ${ }^{10}$ Karena itu orangtua berperan dalam menanamkan karakter spiritual anaknya melalui nilai budaya. Karena seorang anak remaja tidak mungkin menganut budaya orang lain dan meninggalkan budayanya sendiri.

Setiap orangtua Kristen harus terlebih dahulu belajar supaya dapat menjadi pendidik rohani yang baik bagi anak-anaknya. Orangtua harus menjadikan rumahnya sebagai tempat pendidikan dan mengajarkan perintah Allah bagi anakanaknya. Rumah hendaknya tidak hanya sebagai tempat istirahat bagi anggota keluarga dan sebagai tempat berlindung dari terik dan panas matahari. Tetapi juga sebagai lembaga pendidikan, sebagai tempat berkumpul untuk berdoa, menyanyikan pujian kepada Tuhan, dan mempelajari firman Tuhan. Anak-anak adalah generasi penerus jemaat Tuhan, maka mereka perlu diajarkan tentang ketetapan Tuhan secara turun-temurun. Orangtua hendaknya mempergunakan setiap kesempatan untuk mengajarkan perintah Tuhan kepada anak-anaknya. ${ }^{11}$ Sebagai guru pertama dan utama orangtua yang bertanggung jawab mengajarkan ketetapan Allah kepada keturunan berikutnya. Pendidikan agama diawali dari rumah dengan dimulainya belajar berdoa, mendoakan diri sendiri dan seluruh

\footnotetext{
${ }^{10}$ Dennis Mccallum, Gereja Mengagumkan Sesuai Pola Perjanjian Baru, 363-365.

${ }^{11}$ Ibid., 329.
}

anggota keluarga. Persekutuan di tengah keluarga Kristen bukan hanya sebagai persekutuan keluarga yang mendekatkan diri antara sesama anggota keluarga tetapi menjalin hubungan yang intim dengan Tuhan.

\section{Peran Orangtua dalam Pandangan Ilmu Psikologi}

Menurut Singih D. Gunarsah, orangtua teramat penting sebagai "tempat persemaian" dari benih-benih yang akan tumbuh dan berkembang lebih lanjut. Anak yang baru dilahirkan berada dalam keadaan lemah, tidak berdaya, tidak bisa apa-apa, tidak dapat mengurus dirinya sendiri, dan tidak bisa memenuhi kebutuhannya sendiri. Anak yang baru dilahirkan ibarat kertas putih kosong yang masih polos, bagaimana kertas dikemudian tergantung kepada orang yang akan menulisinya. Orangtua menjadi penulis utama kertas kosong itu, langsung atau tidak langsung, memberikan perangsangan (stimulasi) melalui berbagai corak komunikasi antara orangtua dengan anak. Orangtua menjadi faktor terpenting dalam perkembangan dan mengembangkan kepribadian anak yang akan menentukan corak dan gambaran kepribadian setelah dewasa. ${ }^{12}$ Kepribadian seorang anak akan tergantung dari peran orangtua dalam membentuknya. Orangtua yang akan menciptakan karya unik dalam diri anaknya termasuk anak yang sudah remaja. Orangtua yang menjadi penulis utama harus memiliki konsep yang jelas untuk dituliskan agar menjadi sebuah maha karya dalam diri anaknya. Anak menjadi cerminan karya orangtua karena merekalah yang menanamkan seluruh nilai-nilai kehidupan itu.

Anak adalah subjek yang memiliki

\footnotetext{
${ }^{12}$ Singgih D. Gunarsa dan Y Singgih D. Gunarsa, Psikologi Praktis: Anak, Remaja dan Keluarga (Jakarta: BPK Gunung Mulia, 2016), 103-105.
} 
potensi dan kemampuan untuk diaktualisasikan. Dalam proses perkembangannya, anak memerlukan pendampingan serta kondisi yang menantang dan kondusif sehingga anak menjadi pribadi yang berkembang sesuai dengan diri pribadinya yang unik. Orangtua memelihara pertubuhan fisik, kesehatan anak, menginternalisasikan nilai-nilai budaya, agama, kemanusiaan, kemasyarakatan dan nilai-nilai luhur lainnya. Melalui pendidikan di tengah keluarga terjadilah proses enkulturasi secara informal. Keluarga secara tidak langsung menjadi model yang ditiru oleh anak. Pendidikan karakter diterima anak secara tidak langsung melalui kehidupan pribadi orangtua. Hal-hal yang dapat diteladani anak misalnya, ketaatan dalam hukum, aturan, menjalankan kaidah agama, kesusilaan, semangat, dan motivasi hidup yang dipraktekkan orangtua dalam kehidupan sehari-hari akan terekam secara tidak langsung dalam pikiran anak. Kehidupan rumah tangga memiliki pengaruh kuat terhadap kepercayaan diri, daya juang, motivasi, prestasi belajar, kehidupan spiritual, konsep diri, harga diri, kemandirian, tanggung jawab, ketangguhan, dan harapan masa depan anak. ${ }^{13}$ Seluruh kehidupan keluarga dan aktivitas di dalamnya adalah di bawah pengawasan dan pengaruh orangtua. Perkembangan fisik dan psikis anak dalam keluarga juga menjadi tanggung jawab orangtua. Orangtua mengambil peranan penting dalam membentuk karakter anak termasuk salah satu darinya adalah karakter spiritualnya. Orangtua sangat mempengaruhi perkembangan rohani melalui praktek rohani yang dilakukan di rumah dan kebiasaan persekutuan rohani lainnya.

Menurut Grolnick, Santrock, Eggen sebagaimana dikutip Nyoman

\footnotetext{
${ }^{13}$ Nyoman, Op.Cit., 105.
}

mengatakan bahwa orangtua memiliki peran yang sangat penting dan utama dalam perkembangan kepribadian anak. Orangtua dalam mengasuh anak memiliki peran yang signifikan dalam perkembangan personal anak. Perkembangan personal anak menyangkut seluruh aspek kepribadiannya yang akan membentuk karakternya. Peran orangtua dalam mendidik anak dikategorikan dalam empat kelompok pola asuh, yaitu: (1) authorative parenting atau pola asuh demokratis di mana dalam mendidik anak menempatkan anak setara dengan orangtua. (2) authoritarian parenting atau pola asuh otoriter yang membuat anak sebagai objek yang dianggap tidak dapat mengembangkan diri sendiri dan anak harus mendasari proses berpikir dan berperilaku sesuai dengan apa yang dikehendaki dan orangtua menjadi pusat pembelajaran, menjadi panutan yang dijadikan model oleh anak. (3) permissive parenting atau pola asuh yang tidak memiliki pedoman, sengaja atau tidak sengaja, melakukan pembiaran anak dalam melakukan tugas-tugas perkembangannya. (4) uninvolved parenting atau pola asuh pembiaran di mana anak menata kehidupannya sendiri dan mengambil keputusan sesuai dengan kemauan anak. ${ }^{14}$ Perkembangan sifat dan perilaku yang ditunjukkan oleh seorang anak merupakan produk dari pengasuhan orangtua. Dampak peran orangtua dalam mengasuh dan mendidik anak berlangsung sepanjang hidup. Orangtua yang bijak akan dapat menentukan pola asuh yang tepat untuk membentuk karakter setiap anak di dunia ini. Orangtua di dunia ini tidak ada satu pun yang menginginkan anaknya menjadi manusia yang tidak patuh, untuk mencapai hasil yang maksimal dalam pola asuh maka perlu pemahaman psikologis ini dimiliki. Pemahaman yang kurang dalam

${ }^{14}$ Ibid., 105-108. 
pola asuh anak akan berdampak pada hasil yang dicapai dalam pembentukan karakter anak.

Menurut Junihot, orangtua adalah pemberi kasih sayang yang mendasar dan hal ini berpengaruh kuat pada perkembangan psikologi anaknya. Orangtua yang memiliki pemahaman yang cukup tentang bagaimana mendidik anak, akan dapat menjalankan tugasnya dengan baik. Pengetahuan yang diperoleh dapat digunakan dengan optimal untuk membina karakter anaknya. Hal-hal yang mendukung perkembangan psikologi anak yang perlu diketahui orangtua ada dua yaitu: (1) Penerimaan tanpa syarat. Orangtua menerima anaknya bukan perangainya, karena itu seperti apapun keadaannya anak akan selalu diterima orangtua. (2) Stimulasi. Orangtua harus melibatkan diri dalam peningkatan prestasi anak dalam segala aspek, yang dapat dilakukan melalui audio, visual, dan kinetik serta keterlibatan langsung dengan sentuhan, merasai dan membaur. ${ }^{15}$ Keberhasilan seorang anak tergantung kepada bagaimana orangtua memperlakukannya di rumah. Anak akan dapat melalui proses pencapaian dengan baik bila ada keterlibatan orangtua sebagai stimulan.

Menurut Dennis Mccallum, mengatakan bahwa Injil harus toleran terhadap budaya yang dimiliki oleh para remaja. Remaja dalam budaya tradisional menerima saja ritual yang mereka harus lalui dalam sistem keyakinan masyarakat desanya tanpa mempertanyakan apa-apa. Budaya orangtua dan budaya anak-anak mereka harus sama, supaya mereka tidak berada pada dunia yang berbeda. Tindakan ini harus menjadi strategi gereja agar tidak terjadi pergeseran budaya. Mengenai orangtua menanamkan budaya kepada

\footnotetext{
15 Junihot, Op.Cit., 97-99.

${ }^{16}$ Dennis Mccallum, Op.Cit., 363-365.
}

anaknya didukung oleh 1 Korintus 7:17-18 mengatakan: "Selanjutnya hendaklah tiaptiap orang tetap hidup seperti yang telah ditentukan Tuhan baginya dan dalam keadaan seperti waktu dipanggil Allah. Inilah ketetapan yang kuberikan kepada semua jemaat. Kalau seorang dipanggil dalam keadaan bersunat, janganlah ia berusaha meniadakan tanda-tanda sunat itu. Dan kalau seorang dipanggil dalam keadaan tidak bersunat, janganlah ia mau bersunat." ${ }^{16}$ Karena itu orangtua berperan dalam menanamkan karakter spiritual anaknya melalui nilai budaya. Karena seorang anak remaja tidak mungkin menganut budaya orang lain dan meninggalkan budayanya sendiri.

\section{Pembentukan Karakter Spiritualitas Remaja}

\section{Pemahaman Mengenai Remaja}

Menurut KBBI remaja adalah anak yang mulai dewasa. ${ }^{17}$ Menurut Nyoman Surna masa remaja adalah masa saat seorang anak mengalami proses perkembangannya. Remaja senantiasa mengeksplorasi pengalaman-pengalaman baru dalam kehidupannya. Remaja bereksperimen dan berhadapan dengan berbagai macam aturan dan orang-orang yang berbeda. Pada masa remaja terjadi perubahan bentuk tubuh, perkembangan emosional dan kecerdasan. Perkembangan remaja perlu dikawal agar berhasil menjalaninya. Tugas ini tergantung pada keberhasilan orangtua, guru dan remaja itu sendiri. ${ }^{18}$ Remaja mulai mencari jati dirinya untuk menuju kedewasaan dan dalam situasi inilah mereka disebut masih labil. Belum ada prinsip pemikiran yang jelas, belum dapat memutuskan dan mengambil suatu kesimpulan yang tepat, karena itu mereka perlu pembimbingan.

\footnotetext{
${ }^{17}$ KBBI, 1389.

${ }^{18}$ Nyoman Surna, Op.Cit., 132.
} 
Menurut Junihot ${ }^{19}$ masa remaja disebut sebagai periode pubertas (latin) yang artinya "menjadi dewasa" (becoming adult). Usia remaja dimulai dengan usia tiga belas tahun. Pada usia ini mulailah timbul kesadaran akan kebutuhan dihargai, diajak bertukar pikiran, dan karena inilah sering disebut masa transisi. Ada tiga tahapan asa remaja dengan ciri khas dan tugas perkembangannya. Ketiga tahapan itu adalah:

a. Remaja awal, usia 13-15 tahun. Pada usia ini terjadi perubahan suara, bentuk, dan ukuran fisik. Mulai sadar bahwa dirinya bukan lagi anak kecil yang suka lari-larian. Cenderung mencari teman dan membentuk "geng". Selalu ada cara untuk membuat humor atau kegiatan yang lucu, penuh tantangan yang merupakan kenikmatan bagi mereka.

b. Remaja madya, berusia 15-17, pada usia ini akan timbul perasaan yang diwarnai oleh perasaan gelisah, tidak aman, dan kurang pecaya diri.

c. Remaja lanjut, berusia 18-21 tahun. Umumnya para remaja mengalami ketegangan atau kestabilan karena tidak takut lagi ditinggalkan oleh teman-temannya.

Menurut teori perkembangan kognitif, Jean Piaget menyatakan remaja sudah mampu berfikir secara formaloperasional yang ditandai dengan adanya sikap-sikap yaitu: 1) deduktif hipotesis, induktif ilmiah, serta memikirkan kemungkinan-kemungkinan

(probabilitas) dan reflektif; 2) pemikiran remaja juga bersifat kombinatoris, atau mengombinasikan berbagai informasi dan gagasan.

Menurut seorang pendeta yang sekaligus adalah psikolog George Craft, ${ }^{20}$ yang punya pendapat yang sama dengan

\footnotetext{
${ }^{19}$ Junihot, Op.Cit., 99-100
}

Gordon Allport (seorang psikolog) yang mengatakan ada 6 ciri perilaku remaja yang berkembang semakin dewasa dengan keutamaan-keutamaan iman, cinta, dan sifatnya yang teologis. Pembandingan ini kiranya dapat mendukung keabsahan ciriciri orang Kristen yang dewasa. Iman, hidup, harapan, dan cinta mengatur seseorang untuk selalu terbuka terhadap hidup, sadar dan yakin kepada diri sendiri, mempunyai arah dan komitmen. Ke-6 perilaku yang mencirikan bahwa remaja dan pemuda semakin menuju kedewasaan adalah :

- Rasa diri yang berkembang. Seorang pribadi yang semakin menuju kedewasaan mampu mengatasi dirinya sendiri, ikut terlibat dengan orang lain, mempunyai berbagai komitmen dengan orang lain, baik di bidang agama, politik, pekerjaan, pelajaran, keluarga ataupun dalam pergaulan.

- Bergaul dengan orang lain dengan hangat. Ingin akrab dengan orang lain, mempunyai keprihatinan terhadap kebutuhan orang lain, dan dapat memberikan cinta.

- Adanya penerimaan diri sendiri. Dapat menanggapi kebutuhan-kebutuhan diri secara realistis sehingga mampu mengontrol dorongan-dorongan dalam diri, mampu menghadapi frustasi, kekecewaan, dan berbagai macam keragu-raguan.

- Memiliki persepsi. Memiliki gagasan yang realistis sesuai dengan kemampuan, memiliki sikap dan keterampilan sebagai hasil interaksi dengan masyarakat, mampu menyelesaikan tugas-tugas dengan baik dan bertanggungjawab, dan mampu memahami situasi dan keadaan ekonomi hidupnya.

${ }^{20}$ Charles M. Shelton SJ, Menuju Kedewasaan Kristen (Yogyakarta, Kanasius, 1988), 94-96. 
- Objektivitas diri. Memiliki wawasan dan rasa humor karena mampu memahami dirinya secara murni, karena telah mengenal diri sendiri, siapakah aku sesungguhnya. Pemahaman akan diri sendiri ini akan membangun interaksi dengan orang lain dan dunia luar.

- Mempunyai filsafat hidup yang menyatu. Mampu mengembangkan filsafat hidup yang menyatukan berbagai macam unsur yaitu nilai, tujuan dan pandangan-pandangan yang membuat hidup lebih terarah. Memilih agama dan iman kepercayaan merupakan tujuan dari arah hidup remaja dan pemuda.

\section{Pemahaman Mengenai Karakter}

\section{a. Secara Umum}

Dalam Kamus Besar Bahasa Indonesia (KBBI) pengertian karakter adalah sifat-sifat kejiwaan, ahlak atau budi pekerti yang membedakan seseorang dengan yang lain. ${ }^{21}$ Menurut Henk ten Napel karakter (character) artinya watak, tabiat, budi pekerti, perangai, sikap khas. ${ }^{22}$ Karakter yang dimiliki seorang remaja akan sangat mendukung dalam menggapai masa depan yang dicita-citakannya. Sesuatu yang khas dalam diri seorang remaja yang membuatnya berbeda dengan yang lain menjadi satu faktor yang sangat penting diperhatikan. Maka perlu diperhatikan pendidikan karakternya guna mencapai harapan yang diinginkan dari seorang remaja.

\section{b. Menurut Para Ahli}

$$
\begin{gathered}
\text { Menurut para ahli beberapa } \\
\text { pengertian karakter: }
\end{gathered}
$$

\footnotetext{
21 KBBI, Edisi Kelima, (Jakarta: Badan Pengembangan dan pembinaan bahasa kementrian pendidikan dan kebudayaan, CV. Adi Perkasa, 2018), 754.
}

- Menurut Maxwell pengertian karakter sebenarnya jauh lebih baik dibandingkan dengan sekedar perkataan. Lebih dari hal tersebut, karakter merupakan pilihan yang dapat menentukan sebuah tingkat kesuksesan dari seseorang.

- Menurut Wyne pengertian karakter menandai bagaimana teknis maupun cara yang digunakan dalam memfokuskan penerapan dari nilainilai kebaikan ke dalam sebuah tingkah laku maupun tindakan.

- Menurut Kamisa pengertian karakter merupakan sifat kejiwaan, akhlak serta budi pekerti yang dimiliki seseorang yang membuatnya berbeda dibandingkan dengan orang lainnya. Berkarakater juga dapat diartikan sebagai memiliki sebuah watak serta kepribadian.

- Menurut Doni Kusuma pengertian karakter adalah sebuah gaya, sifat, ciri, maupun karakteristik yang dimiliki seseorang yang berasal dari pembentukan atupun tempaan yang didapatkannya melalui lingkungan yang ada di sekitar.

- Menurut Gulo W. pengertian karakter merupakan kepribadian yang dapat dilihat dari titik moral maupun tolak etis, misalnya saja kejujuran seseorang. Biasanya karakter memiliki hubungan pada sifat-sifat yang umumnya tetap.

- Menurut W.B Saunders pengertian karakter adalah sifat yang nyata serta berbeda yang mana ditunjukkan oleh seseorang. Jarakter tersebut dapat dilihat dari beragam macam atribut di dalam tingkah laku seseorang.

\footnotetext{
${ }^{22}$ Henk ten Napel, Kamus Teologi (Jakarta: BPK: Gunung Mulia, 1994), 73.

${ }^{23}$ Khanza Savitra, Pengertian Karakter menurut para Ahli (28 September 2019): diakses 20 September 2019, https://dosenpsikologi.com/.
} 
- Menurut Alwisol pengertian karakter adalah penggambaran dari tingkah laku yang dilakukan dengan memperlihatkan serta menonjolkan nilai, baik itu benar atau salah secara implisit maupun eksplisit. Karakter tentu berbeda dengan sebuah kepribadian yang memang di dalamnya tidak menyangkut nilai sama sekali.

- Menurut Soemarno Soedarsono pengertian karakter merupakan sebuah nilai yang sudah terpatri di dalam diri seseorang melalui pengalaman, pendidikan, pengorbanan, percobaan, serta pengaruh lingkungan yang kemudian dipadupadankan dengan nilai nilai yang ada di dalam diri seseorang dan menjadi nilai intrinsik yang terwujud di dalam sistem daya juang yang kemudian melandasari sikap, perilaku, dan pemikiran seseorang.

- Menurut Ryan \& Bohlin pengertian karakter merupakan sebuah pola perilaku seseorang. Orang dengan karakter yang baik tentu saja akan paham mengenai kebaikan, menyenangi kebaikan, serta mengerjakan sesuatu yang baik pula. Orang dengan perilaku yang memang sesuai kaidah moral disebut sebagai orang yang berkarakter mulia.

- Menurut Drs. Hanna Djumhana Bastaman M.Psi pengertian karakter merupakan bentuk dari aktualisasi diri serta internalisasi nilai serta moral yang berasal dari luar menjadi satu ke dalam bagian kepribadiannya.

- Menurut Kemendikbud pengertian karakter merupakan bentuk cara berpikir serta berperilaku seseorang yang nantinya akan menjadi ciri khasnya.

\footnotetext{
24 Thomas Lickona, Character Matters (Persoalan Karakter) (Jakarta: Bumi Aksara, 2015), 15-16.
}

- Menurut Pusat Bahasa Depdiknas (2008) pengertian karakter merupakan bawaan dari hati, jiwa, budi pekerti, kepribadian, sifat, tabiat, personalitas, temperamen, dan watak. Berkarakter dapat pula diartikan sebagai kepribadian, bersifat, berperilaku, berwatak, dan bertabiat.

- Menurut Thomas Lickona karakter adalah objektifitas yang baik atas kualitas manusia dan isi karakter itu sendiri adalah kebaikan-kebaikan seperti, kejujuran, keberanian, keadilan, dan kasih sayang. Kebaikankebaikan yang dinilai oleh masyarakat dan agama. Melalui kebaikan itu seseorang akan mengerti apa tugasnya sebagai manusia yaitu berbuat kebajikan, murah hati, tidak egois, adil dan jujur. Dengan kebajikan seseorang akan bahagia dan sejahtera. Orang yang berkarakter adalah orang yang melayani kepentingan umum dan melakukan banyak hal untuk masyarakat luas. ${ }^{24}$

Pendidikan karakter muncul sejak tahun 1990-an di Amerika Serikat disaat terjadinya penurunan kesadaran dan keruntuhan moral masyarakat, khususnya moral kaum muda. Saat itu terjadi hal yang memprihatinkan seperti meningkatnya kejahatan, bunuh diri dikalangan remaja, perceraian, aborsi, kebiasaan menyontek dikalangan siswa, kebiasaan mencuri barang dari toko di kalangan remaja. Di Indonesia pendidikan karakter ini sangat perlu untuk mengatasi kerusakan moral masyarakat yang sudah berada pada tahap mencemaskan. Perilaku yang mencemaskan di kalangan kaum muda seperti mencontek, mengkonsumsi narkoba, tindakan kekerasan, pornografi, seks bebas, tidak peduli pada aturan, tidak peduli etika dan sopan santun. ${ }^{25}$

\footnotetext{
${ }^{25}$ Saptono, Dimensi-dimensi Pendidikan Karakter, (Jakarta: Erlangga, 2011), 17-19.
} 
Dari beberapa pengertian di atas dapat diambil suatu pemahaman mengenai karakter yaitu hal-hal yang menyangkut tentang sifat, kepribadian dari seseorang yang menjadi ciri khasnya. Setiap orang tentunya berbeda-beda sifat dan kepribadiannya tergantung bagaimana sikap hidup yang dijalaninya. Karakter itu adalah cara bertindak, berpikir, berperilaku dan menjadi sifat atau kepribadian yang khas dari seseorang. Karakter seseorang dapat dipengaruhi cara berpikirnya, ketertarikannya kepada sesuatu, kebiasaan yang dilakukan dan itulah menjadi ciri khasnya. Hal-hal dari luar diri manusia dapat mempengaruhi karakternya sehingga jika menginginkan sesuatu yang baik hendaklah selalu memikirkan yang baik dan berhubungan dengan orang yang baik saja. Demikian karakter yang dapat dilihat dalam diri setiap orang.

\section{Pemahaman Mengenai Spiritualitas}

\section{a. Pengertian Spiritualitas}

Dalam KBBI Spiritualitas artinya adalah sumber motivasi dan emosi pencarian individu yang berkenaan dengan hubungan seseorang Tuhan. ${ }^{26}$ Menurut Henk ten Napel mengartikan spiritualitas sebagai kerohanian (spirituality). 27 Menurut Samuel Sijabat, Spiritualitas merupakan kekuatan yang semata-mata bersumber dari manusia, sebagai upaya dirinya untuk mendemonstrasikan hidup yang berarti bagi sesamanya. Spiritualitas dimengerti sebagai keterkaitan batin manusia dalam mengerti, menanggapi serta mengambil sikap dan keputusan dalam realitas dan tujuan hidup manusia. Spiritualitas (dari bahasa Latin) atau spirituality (Inggris) berarti keadaan tidak berwujud material dari suatu substansi.

\footnotetext{
${ }^{26}$ KBBI., 1590.

${ }^{27}$ Henk ten Napel, Op.Cit, 296.
}

Bagi orang Kristen spiritualitas itu adalah tehnik-tehnik meningkatkan pengalaman rohani, tinggi rendahnya kadar kerohanian, aktivitas atau kegiatan kerohanian, dan gerakan asketisme, pietisme, emosi keagamaan. ${ }^{28}$ Dalam membentuk karakter spiritualitas remaja hal di atas perlu dipahami oleh pembimbing spiritual remaja. Hal itu akan memberi kemudahan dalam mengajarkan hal-hal keagamaan kepada para remaja.

\section{b. Prinsip-Prinsip Pengembangan Spiritualitas $^{29}$}

\section{1) Sumber Spiritualitas}

Sumber daya rohani setiap orang Kristen adalah Yesus Kristus, yang dinyatakan-Nya melalui kehadiran dan kerja Roh-Nya yang kudus. Roh Allah saja yang akan memberi spiritualitas sejati dalam hidup seseorang tetapi hal itu akan diterima apabila seseorang itu membuka diri. Menurut Schaeffer, spiritualitas sejati dimulai dari kelahiran kembali oleh kehadiran dan pekerjaan Roh Allah. Relasi dengan Allah di dalam Yesus Kristus akan memerdekakan orang percaya dari kuasa dosa, pemahaman akan semakin sempurna akan kedudukan sebagai anak-anak Allah (Roma 8:15-16; Gal. 4:6-7).

\section{2) Landasan Spiritualitas}

Landasan spiritualitas orang percaya adalah berakar dalam firman Allah (bnd. Mzm. 119; 2 Tim. 3:16-17; Yoh. 8:31-32). Mengapa demikian? Karena firman Allah memberikan kemerdekaan dari kuasa dosa, kebebasasan dari kebodohan, dan kepicikan iman. Firman Allah memberikan prinsip, nilai, dan tatanan hidup sehari-hari, bagaimana kita hidup secara bijaksana, menghadapi situasi

\footnotetext{
${ }^{28}$ Samuel B Sijabat, Strategi Pendidikan Kristen, $217-218$

${ }^{29}$ Ibid., 219-225.
} 
mujur maupun malang. Menurut Lawrence, meski tidak ada dituliskan kata spiritualitas dalam Alkitab namun berisi perkara-perkara hidup rohani Kristiani.

\section{3) Bentuk atau Jenis Spiritualitas}

Dalam menghadapi realitas kehidupan, maka Kristus mengadakan perubahan dalam hidup orang yang percaya kepadanya melalui spiritualitas yang creative spirituality (2 Kor. 5:17), spiritualitas siap tempur spirituality for combat dalam realitas peperangan rohani (Ef. 6:11-13; 1 Pet. 5:8).

\section{4) Profesionalisme Spiritualitas}

Memiliki sesuatu untuk diakui dare to profess something, mampu membimbing lebih profesional dalam melaksanakan praktek hidup setiap hari. James Michael Lee mengatakan spiritualitas yang perlu dikembangkan pada masa yang akan datang adalah yang berani mendorong kita tampil lebih berani mendemonstrasikan gaya hidup yang khas sebagai orang Kristen.

\section{5) Sifat Spiritualitas}

Karena manusia pada umumnya bersifat dinamis maka demikian juga kadar spiritualitasnya bersifat dinamis. Daya spiritualitas orang Kristen akan semakin berkembang saat menghadapi krisis-krisis psikologis dan sosiologis dalam perjalanan hidup, dalam mencapai tujuan akhir (destiny of life).

Menurut Stephen R. Covey, spiritualitas adalah salah satu dari dimensi pembaharuan diri. Dalam memelihara dan meningkatkan aset terbesar dalam diri manusia ada empat dimensi alamiah yang memperbaharuinya. Keempat aspek tersebut adalah fisik, spiritual, mental, dan sosial emosional. Dalam filsafat kehidupan keempat dimensi alamiah ini berhubungan secara eksplisit atau implisit. Filsuf Herb Shepherd menjabarkan kehidupan sehat yang seimbang di sekitar empat nilai: perspektif (spiritual), otonomi (mental), keterkaitan sosial, dan tonus (fisik), George Sheehan menjabarkan empat peran: menjadi binatang yang baik (fisik), ahli pertukangan yang baik (mental), teman yang baik (sosial), dan orang suci (spiritual). Dimensi spiritual adalah daerah yang amat pribadi dari kehidupan dan sangat penting. Dalam meditasi penuh renungan harian dari kitab suci, membuat perasaan diperbaharui, diperkuat, dipusatkan dan memiliki komitmen kembali untuk bekerja. ${ }^{30}$ Spiritualitas menjadi salah satu dimensi pembaharuan diri melalui perenungan. Dengan membaca Alkitab dan berdoa seseorang akan mendapat kekuatan dalam melakukan segala pekerjaannya. Spiritualitas

\section{Pemahaman Mengenai Karakter Spiritualitas}

Dalam usaha untuk membantu anak menyelesaikan masalahnya maka perlu pengenalan akan anak. Sebagai usaha mengenal anak dapat dimengerti tingkah laku anak, latar belakang masalahnya, selanjutnya dapat diberi cara untuk menyelesaikan masalahnya. Pemahaman mengenai kebutuhan anak turut juga mempengaruhi pengenalan terhadap karakter spiritualitasnya. Menurut Singgih, salah satu dari hal-hal umum yang perlu diperhatikan dari perkembangan anak yaitu "minat religi". Anak remaja mempunyai minat terhadap religi (rohani), maka akan sangat baik bila diberikan dasar-dasar pegangan hidup bagi yang sedang dibentuk. Selanjutnya perlu juga diajarkan bagaimana penyaluran

\footnotetext{
30 Stephen R. Covey, The 7 Habits of Higly
} Effective People, 326-333. 
minat religi, apakah mengadakan penelaahan Alkitab, ikut bernyanyi dalam koor, belajar mengaji. Bila hal ini telah dipahami maka dapat diperoleh gambaran yang jelas tentang masalah rohani anak dengan sebab akibatnya. Dengan adanya pengenalan masalah keinginan remaja maka dengan mudah dan cepat dapat mengetahui cara mengatasinya. ${ }^{31}$

Memahami karakter remaja bagi para pembinanya sangatlah perlu, karena dengan demikian akan dapat membantu untuk membuatnya menjadi manusia yang lebih baik. Para pembina remaja dapat menolong mereka untuk menemukan jati dirinya. Memahami spiritualitas remaja bagi para pembinanya juga hal yang memungkinkan menolong para pendidik Kristen ini untuk mengarahkannya semakin dekat kepada Tuhan. Karakter spiritualitas remaja adalah cara berpikir atau berperilaku dari seorang remaja dalam hubungannya dengan Tuhannya. Melalui kedekatan seorang remaja dengan Tuhan akan tercipta sebuah mahakarya dalam dirinya. Allah akan berkarya melalui diri seorang remaja, menjadikannya manusia yang berguna. Sebagaimana tugas dan panggilan seorang Kristen menjadi garam dan terang, demikian seorang remaja dapat dibentuk sesuai dengan panggilannya. Untuk dapat mengembangkan karakter spiritualitas remaja maka dirasa perlu memahami seperti apakah seorang remaja dalam tumbuh kembangnya. Berikut akan dicoba mengambil suatu pengertian dan pemahaman mengenai remaja itu untuk memudahkan para orangtua dan pendidik Kristen dalam melalukan pembinaan kepada mereka.

\footnotetext{
${ }^{31}$ Singgih D Gunarsah, Op.Cit., 66.
}

\section{Peran Orangtua dalam Pembentukan Karakter Spiritualitas Remaja}

Remaja merupakan subjek utama dari penelitian penulis, dikatakan demikian karena tujuan dari tulisan ini adalah agar para remaja menjadi pribadi yang dikehendaki Tuhan. Dalam istilah khotbah Kristen dikatakan menjadi orang yang berkenan di hadapan Tuhan. Dalam membentuk mereka menjadi pribadi yang berkenan di hadapan Tuhan maka ada orang yang terlibat di dalamnya. Sesuai dengan hakikat seorang remaja yang masih labil dan masih mencari jati diri maka dibutuhkan pengaruh dari luar dirinya untuk dapat menjadikannya dewasa. Jika sudah ada yang dapat mempengaruhi mereka maka dibutuhkan alat untuk mempengaruhinya. Orangtua adalah orang yang sangat dimungkinkan dapat mempengaruhi mereka dan pembinaan karakter spiritualitas yang menjadi alatnya. Pertanyaannya adalah apakah semua orangtua mengerti akan perannya dan adakah kurikulum yang jelas sebagai alat untuk dipakainya? Orangtua adalah pendidik dan kurikulumnya adalah pendidikan karakter spiritualitas.

Allah adalah pribadi pendidik yang agung dan Kristus adalah guru agung umat percaya. Dalam mendidik umat-Nya ada unsur pengajaran, ganjaran, disiplin, dan hukuman dan ini perlu dimiliki orangtua. Maka ajarlah anak-anak pada jalan yang benar. Berilah upah atau pujian ketika mereka berbuat yang benar. Bila mereka berbuat salah tegurlah dengan kasih dan memberi pengertian. Kecenderungan orangtua adalah menginginkan anakanaknya menjadi anak yang berbakti dan berguna bagi keluarga. Orangtua juga berharap anaknya menjadi lebih baik daripada orangtuanya, secara moral, prestasi, ekonomi, dan kerohaniannya. ${ }^{32}$

${ }^{32}$ Sudiyono, Op.Cit., 87. 
Hal itu akan terwujud dalam diri anak yang dari sejak muda telah diperkenalkan jalan yang harus ditempuh dalam menggapai cita-citanya dengan mencari kerajaan Allah. Memperkenalkan Tuhan sejak muda maka para remaja akan mencintai jalan dan kehendak Tuhan. Pengaruh buruk tidak akan menjangkau remaja yang telah membentengi diri dengan iman kepada Tuhan pemilik hidup ini.

Budiono Adi Wibowo mengatakan bahwa dari segi tujuan pendidikan, dan peran remaja sebagai naradidik yang sedang dipersiapkan untuk masa depan adalah sesuatu yang wajar. Namun perlu diingat juga bahwa sudut pandang demikian menempatkan remaja sebagai obyek dan kurang menempatkannya sebagai subyek. ${ }^{33}$ Pernyataan Wibowo ini mengingatkan bahwa meskipun gereja bertugas untuk menghantarkan remaja pada pemahaman-pemahaman dan perjalanan menuju masa depan yang lebih baik bersama Allah, namun hal penting yang harus diingat adalah remaja itu sendiri adalah para pembawa pengharapan. Remaja adalah subyek yang bisa membawa dunia pada kehidupan yang lebih baik di masa depan. Oleh sebab itu, mereka harus dibekali oleh pendidikan iman yang baik sejak dini.

Gereja sebagai tempat untuk mendidik dan menumbuhkan iman remaja memiliki tugas pendidikan seperti sebuah sekolah. Pendidikan berasal dari bahasa Latin educare yang berarti "menuntun ke luar." Thomas Groome menyebutkan bahwa ada tiga dimensi yang dapat dilihat dalam "menuntun ke luar," yakni: 1) titik berangkat dari mana, 2) proses masa kini, dan 3) masa depan ke arah mana tuntunan dilaksanakan. ${ }^{34}$

Jika orangtua memiliki peran utama sebagai pendidik maka terlebih

33 Budiono Adi Wibowo, Gereja Mendampingi Remaja (Jakarta: BPK Gunung Mulia, 2002), 252. dahulu perlu diberikan pengertian apa itu pendidikan. Menurut Lawrence Cremin sebagaimana dikutip oleh Thomas $\mathrm{H}$. Grome mendefinisikan pendidikan sebagai "usaha sengaja, sistematis, dan terusmenerus untuk menyampaikan, menimbulkan, atau memperoleh pengetahuan, sikap-sikap, nilai-nilai, keahlian-keahlian, atau kepekaankepekaan, juga setiap akibat dari usaha itu." Dalam pendidikan ada penanaman pelajaran-pelajaran (sikap, nilai, keahlian, kepekaan, dll) kepada naradidik yang berdampak pada tumbuh kembang diri naradidik sendiri. Pendidikan itu juga seharusnya dilakukan secara terusmenerus, berkesinambungan agar tali tidak terputus dan naradidik mendapatkan pendidikan yang utuh. ${ }^{35}$

Prinsip-prinsip pendidikan seperti inilah yang perlu untuk diterapkan gereja kepada para remaja sebagai subyek pelayanan (naradidik). Dalam mendidik anak perlu punya kurikulum yang jelas. Pengajaran yang diberikan harus dapat mempengaruhi anak remaja agar hidup kudus di hadapan Tuhan. Ada beberapa pengajaran Alkitab yang dapat diberikan kepada anak remaja seperti di bawah ini.

Beberapa ayat Alkitab PL dan PB mengatakan tentang hidup orang muda atau kita sebut saja remaja : Kitab Mazmur 119:9 Kitab ini mengatakan "Dengan apakah seorang muda mempertahankan kelakuannya tetap bersih? Dengan menjaganya sesuai dengan firmanMu. Artinya adalah bagaimana seorang percaya dapat menjaga kemurnian hidupnya, menolak pengaruh asusila yang menandakan lingkungan fasik di mana kita tinggal? Selanjutnya bait ke-2 dari Mazmur ini mencatat delapan cara yang berikut, masing-masing dalam satu ayat: (1) Dengan membuat keputusan yang tidak

\footnotetext{
34 Thomas H. Grome, Christian Religius Education (Jakarta: BPK Gunung Mulia, 2011), 5.

${ }^{35}$ Ibid., 29.
} 
bisa diubah untuk tetap setia kepada Firman Allah yang tertulis hingga akhir hidup di dunia ini; (2) dengan mencari Tuhan dalam doa; (3) dengan menghafal Firman Allah; (4) dengan mengharapkan bimbingan dari Allah; (5) dengan bersikap terbuka bagi kebenaran Allah; (6) dengan bersukacita serta senang dengan perkataan Allah; (7) dengan mengamat-amati hasil jalan-jalan Allah yang berlawanan dengan jalan dunia; (8) dengan tidak terlalu sibuk untuk membaca dan mempelajari Firman Allah. ${ }^{36}$

Sebuah pertanyaan berbobot yang diajukan. Dengan cara bagaimana angkatan yang akan datang akan menjadi lebih baik daripada angkatan sekarang ini? Dengan apakah seorang muda mempertahankan kelakuannya bersih? Pembersihan menyiratkan bahwa ada yang tercemar. Di samping kebusukan atau kecemaran asali yang kita bawa ke dunia ini bersamaan dengan kelahiran kita (yang darinya kita belum dibersihkan sampai hari ini), ada banyak dosa khusus yang menguasai orang-orang muda, yang dapat mencemari jalan mereka, yakni nafsu orang muda (2 Tim. 2:22). Dosa-dosa ini akan menyakiti hati Allah dan mempermalukan diri mereka sendiri. Orang-orang muda perlu membersihkan kelakuan mereka, supaya hati mereka diperbarui dan kehidupan mereka diubahkan kembali sepenuhnya, dijadikan bersih, dan tetap bersih, serta luput dari hawa nafsu duniawi yang membinasakan dunia, supaya mereka memiliki hati nurani yang murni dan nama yang baik. Hanya sedikit orang muda yang mau bertanya kepada diri sendiri, dengan cara bagaimana mereka dapat memulihkan dan menjaga kesucian mereka. Itulah sebabnya Daud mengajukan pertanyaan itu kepada mereka.
Ada Sebuah jawaban memuaskan diberikan atas pertanyaan ini. Orang-orang muda akan berhasil mempertahankan kelakuan mereka bersih dengan menjaganya sesuai dengan firman Allah. Kehormatan firman Allah itulah yang membuat firman itu memiliki kuasa seperti itu dan dapat memberi manfaat bagi orang per-orang dan masyarakat, yang kebahagiaannya banyak ditentukan oleh kelakuan orang-orang muda mereka.

Dengan demikian maka yang dilakukan orang muda:

a) Remaja harus menjadikan firman Allah sebagai pedoman untuk mengakrabkan diri denganNya, dan berusaha hidup sesuai dengan firman itu. Firman itu mampu membersihkan hati remaja dengan lebih baik daripada hukumhukum para penguasa atau ajaranajaran moral para ahli filsafat.

b) Remaja harus menjalankan pedoman itu dengan cermat dan memetik manfaat dari situ.

c) Remaja harus menaruh perhatian kepada jalan hidupnya, harus mengujinya dengan firman Allah, sebagai batu sentuhan dan norma, harus memperbaiki yang tidak sesuai dan mengarahkannya sesuai dengan peta dan pedoman itu.

Firman Allah tidak akan bekerja tanpa kecermatan kita dan memberikan perhatian kita terus-menerus pada firman itu dan jalan kita, supaya kita dapat membandingkan keduanya bersama-sama. Kehancuran orang muda dapat disebabkan oleh hidup bebas (atau tanpa aturan sama sekali) atau karena memilih pedoman yang salah. Biarlah mereka menempuh jalan yang rata dan berjalan menurut aturanaturan kitab suci, sehingga jalan mereka akan bersih, dan mereka akan memiliki penghiburan serta kehormatan di dunia ini

\footnotetext{
${ }^{36}$ Walter Lamp, Tafsiran Kitab Mazmur ( Jakarta: BPK Gunung Mulia, 1994), 134-136.
} 
dan sampai selama-lamanya.

Surat-surat Paulus. Paulus mengatakan bahwa: "Segala tulisan yang diilhamkan Allah memang bermanfaat untuk mengajar, untuk menyatakan kesalahan, untuk memperbaiki kelakuan dan untuk mendidik orang dalam kebenaran" (2Tim. 3:16). Paulus berbicara tentang Alkitab Perjanjian Lama dan Perjanjian Baru. Pengajaran merupakan sarana yang digunakan untuk memberikan pengetahuan. Dalam Perjanjian Lama dan Perjanjian Baru, Alkitab digunakan untuk mengajar. Taurat Tuhan dalam Perjanjian Lama digunakan untuk mendidik bangsa Israel, sementara kitab-kitab dalam Perjanjian digunakan untuk mengajar jemaat Kristen mula-mula. Alkitab merupakan sumber dari semua pengetahuan (Mzm. 19:7; Ams. 2:6) ${ }^{37}$

Teguran dalam firman Allah tujuannya adalah bahwa orang Kristen yang bersalah ditegur atas dosa-dosa mereka. Mereka dinyatakan bersalah. Mazmur 19:11 dan Ibrani 4:12 menegaskan fungsi Alkitab ini. Memperbaiki kelakuan atau koreksi merupakan sarana yang digunakan untuk "meluruskan kembali" orang Kristen. Alkitab pertama-tama menegur pembaca atas dosa mereka, lalu Alkitab menunjukkan bagaimana menghadapi dosa supaya mereka dapat kembali berjalan bersama Allah. ${ }^{38}$

Mendidik orang dalam kebenaran atau berlatih dalam kebenaran (righteousness): sarana yang digunakan untuk orang percaya dibentuk di jalan yang benar dalam hidupnya. Alkitab mengajar orang kudus bagaimana berjalan dalam jalan kebenaran (Mzm. 23:3). Alkitab menjadi sumber kekuatannya (Mat. 4:4; Kis. 20:32). Allah menghendaki supaya

\footnotetext{
37 Nikolaus Hayon, Tema-tema Paulus (Bogor: Mardi Yuana, 1989), 64.

${ }^{38}$ Ibid., 65.

${ }^{39}$ Nikolaus Hayon, Op.Cit., 66.
}

remaja hidup dalam kebenaran firmanNya karena Alkitab menyatakan kesalahan, Alkitab memperbaiki kelakuan, dan mendidik kita dalam kebenaran firman Allah. Oleh karena itu, identitas diri remaja dan pemuda Kristen haruslah benar-benar berdasar pada Alkitab. ${ }^{39}$

Orangtua adalah sebagai guru utama dan pertama dalam pembentukan karakter spiritualitas remaja. Perkembangan fisik, sosial, intelek, psikologi dan rohani adalah sasaran utama dari perhatian dan pendidikan yang akan diberikan oleh orangtua kepada remaja. Dalam menyampaikan pendidikan karakter tersebut memiliki tahapantahapan. Menurut Junihot ada tiga tahapan keterlibatan orangtua dalam perkembangan anak yaitu: (1) Keterlibatan langsung dan interaksi dengan anak. (2) Menyediakan peluang-peluang bagi pengalaman berbeda. (3) Bekerja sama dengan orang lain atau pihak lain sebagai patner. $^{40}$

Menurut Harianto GP orangtua memegang tanggung jawab utama dalam keluarga dan anggota keluarga lainnya hanya membantu dan sebagai pelengkap. Bertanggung jawab memberi teladan kepada anak, mendidik mereka dalam kasih dan ajaran Tuhan (Ef. 6:4), dan dapat menerima segala keadaan mereka. Sikap yang harus diambil orangtua adalah sikap tegas dalam mengajarkan dan mendisiplinkan anak (bnd. 1 Sam. 2:11-26 tentang kisah anak Eli), memiliki ketekunan (lih. Ul. 6:6-9), serta harus konsisten dalam pengajaran itu. ${ }^{41}$ Prilaku yang ditunjukkan remaja sebagai cerminan dari kualitas pendidikan yang diberikan orangtua. Jika orangtua lemah dalam pengawasan terhadap remaja maka mereka akan terpengaruh dengan keadaan di luar.

\footnotetext{
${ }^{40}$ Junihot, Op.Cit., 100.

${ }^{41}$ Harianto GP. Pendidikan Agama Kristen dalam Alkitab dan Dunia Pendidikan Masa Kini (Yogyakarta: Yayasan Andi, 2012), 70-71,
} 
Harapan akan anak yang membahagiakan dan menjadi kebanggan orangtua akan tinggal harapan tanpa jadi kenyataan.

Menurut Dolores Leckey sebagaimana dikutip oleh Harianto mengatakan bahwa keluarga sebagai "laboratorium kerja rohani" yaitu menjadi tempat belajar praktis dan konkret. Anakanak lebih banyak mengamati perilaku orang-orang dewasa daripada belajar dari perkataan atau nasihat (menjadi kurikulum tersembunyi/hidden curiculum). Oleh karena itu, kurikulum yang dipakai orangtua harus diperjelas terutama pengajaran mengenai siapa Allah dan apa yang Dia ajarkan mengenai kehidupan. ${ }^{42}$

Berkaitan dengan itu maka harus ada juga target yang dicapai, yaitu: Hubungan anak dengan Allah secara pribadi, sifat yang saleh: ketaatan, kemurahan hati, kemurnian, kekudusan, kerendahan hati, dan lain sebagainya. Kepribadian yang sehat: kebahagiaan batiniah yang berdasarkan pada kepercayaan diri sendiri dan Allah; rasa hormat kepada diri sendiri dan orang lain; kemampuan bertindak dengan penuh tanggung jawab. Kemampuan untuk hidup efektif dengan orang lain dalam kelompok, keterbukaan, menunjukkan kesetiaan, pengertian, dan pengampunan. Kemampuan untuk berpikir kritis, terutama dalam menetapkan dan mempertahankan tolak ukur serta nilai yang baik. Kemampuan untuk bekerja kreatif dan menunjukkan diri sendiri sebagai pribadi yang unik. Akal sehat dan penilaian yang baik. ${ }^{43}$

Menurut Jamie Mckenzie sebagaimana dikutip oleh Junihot merumuskan enam poin penting yang perlu diperhatikan oleh seorang pendidik dalam membelajarkan remaja. Jika orangtua adalah sebagai pendidik maka hal

${ }^{42}$ Harianto GP. Op.Cit., 73.

${ }^{43}$ Ibid., 74 berikut perlu diketahui yaitu (1) memberikan arahan yang jelas dan mengurangi kebingungan remaja dan (2) mengembangkan langkah demi langkah berisi petunjuk tindakan yang jelas, (3) membantu remaja memberi pemahaman mengapa mereka melakukan sesuatu yang diperintahkan dan mengapa hal itu penting. (4) menyediakan struktur pelajaran agar tidak menyimpang, (5) menjelaskan harapan dan menggabungkan penilaian dengan umpan balik, (6) menyediakan sumber untuk mengurangi kebingungan, frustasi dan waktu, mengurangi ketidakpastian, kejutan, dan kekecewaan pendidik agar remaja dapat belajar maksimal. ${ }^{44}$

Dengan memahami berbagai penjelasan di atas dapat dilihat bahwa orangtua punya peranan penting dalam pembentukan karakter spiritual remaja. Harapan orangtua menjadi sumber kekuatan dan motivasi utama dalam pendidikan karakter ini. Orangtua mejadi figur utama dan aktor pembentuk karakter spiritual remaja. Teladan yang disebut sebagai kurikulum tersembunyi adalah pengajaran tanpa konsep dan aturan karena itu orangtua harus berhati-hati dalam sikapnya. Guna mensukseskan peran orangtua dalam pembentukan karakter spiritualitas remaja maka selanjutnya dilakukan penelitian.

\section{E. Implikasi terhadap Pendidikan Agama Kristen (PAK)}

Dalam dunia pendidikan saat ini baik pendidikan formal maupun nonformal perlu melihat dan memahami betapa pentingnya suatu model atau metode yang dikembangkan dalam pendidikan karakter. Pendidikan Agama Kristen adalah sebuah usaha yang bersifat pendidikan dan pembelajaran kepada

${ }^{44}$ Junihot, Op.Cit., 101. 
seluruh warga jemaat secara bertahap untuk mengenal Tuhan Yesus Kristus sebagai Tuhan dan Juruselamat pribadi, yang dituliskan dalam Alkitab sebagai sumber utama pembelajaran, dengan demikian setiap peserta didik memiliki pengenalan yang benar akan Anak Allah, kedewasaan penuh, dan keteguhan iman dalam menghadapi berbagai persoalan. Landasan utama dari pendidikan karakter untuk remaja adalah Alkitab. Maka sebagai guru pertama dan utama orangtua berperan mengajarkan Alkitab kepada remaja sebagai kurikulum pembentukan karakter spiritualitasnya. Orangtua adalah rekan sekerja guru PAK di sekolah dan sebaliknya dalam pembinaan karakter spiritualitas remaja.

Pendidikan Agama Kristen adalah sebuah usaha yang bersifat pendidikan dan pembelajaran, peserta didik adalah semua warga jemaat. Sumber utama materi dan kajian Pendidikan Agama Kristen adalah dari Alkitab. Pendidikan Agama Kristen bukanlah sekedar kegiatan biasa, akan tetapi sebuah bentuk usaha sadar dari lembaga gereja, sekolah, dan berbagai lembaga lainnya untuk mencapai tujuannya yang diharapkan dan memerlukan kesiapan dan perencanaan yang matang. Maka PAK harus dapat mengedukasi jemaat dalam seluruh kategorial umur untuk mengenal Allah melalui pemberitaan Alkitab. Sejalan dengan tujuan pendidikan dalam mengedukasi remaja maka orangtua dalam pembentukan karakter spiritual anaknya juga perlu mempersiapkan diri dengan terlebih dahulu.

\section{F. Referensi}

Arikunto, Suharsimi. Prosedur Penelitian, Suatu Pendekatan Praktik. Jakarta: Rineka Cipta, 2006.

Baskoro, Danang. Menjadi Lebih Baik (Parenting Healing). Jakarta: Kompas Gramedia, 2018.
Covey, Stephen R. The 7 Habits Of Higly

Effective People/7 Kebiasaan Manusia yang sangat Efektif. Tangerang Selatan: Binarupa Aksara Publiser, 2006.

Gunarsah, Singgih D. dan Y Singgih D. Gunarsah. Psikologi untuk Membimbing. Jakarta: BPK Gunung Mulia, 1995. dan Y Singgih D. Gunarsa, Psikologi Praktis: Anak, Remaja dan Keluarga. Jakarta: BPK Gunung Mulia, 2016.

Grome, Thomas H. Christian Religius Education. Jakarta: BPK Gunung Mulia, 2011.

Griffiths, Michael. Gereja dan Panggilannya Dewasa ini. Jakarta: BPK Gunung Mulia, 1991.

Harianto GP. Pendidikan Agama Kristen dalam Alkitab dan Dunia Pendidikan Masa Kini, Yogyakarta: Andi, 2012.

Hayon, Nikolaus. Tema-Tema Paulus. Bogor: Mardi Yuana, 1989.

Junihot S. Psikologi Pendidikan Agama Kristen. Yogyakarta: Andi, 2016.

KBBI, Edisi Kelima. Jakarta: Badan Pengembangan dan pembinaan bahasa kementrian pendidikan dan kebudayaan, CV. Adi Perkasa, 2018.

Lamp Walter. Tafsiran Kitab Mazmur. Jakarta : BPK Gunung Mulia, 1994.

Denis McCallum, Gereja yang Mengagumkan Sesuai Pola Perjanjian Baru. Yogyakarta: Andi, 2018.

Lickona, Thomas. Character Matters (Persoalan Karakter). akarta: Bumi Aksara, 2015.

Napel Henk ten. Kamus Teologi. Jakarta: BPK. Gunung Mulia, 1994.

Saptono. Dimensi-dimensi Pendidikan Karakter. Jakarta: Erlangga, 2011.

Sijabat, B. Samuel. Strategi Pendidikan Kristen. Yogyakarta: Andi, 1996.

Sudiyono dan Ruth Purweni. Generasi 
Jurnal Pendidikan Agama Kristen SHANAN

Volume 3 Nomor 2 Tahun 2019 hal. 95-114

Akhir Zaman yang Dirindukan

Tuhan. Yogyakarta: Andi, 2017.

Surna, I Nyoman \& Olga D. Pandeirot, Psikologi Pendidikan 1. Jakarta: Erlangga, 2014.

Wibowo, Budiono Adi. Gereja Mendampingi Remaja. Jakarta: BPK Gunung Mulia, 2002.

Wiriadinata, Susan S., Ardi Wiriadinata, dan John Sudarma. Mengasuh Anak Mengasihi Tuhan. Jakarta: Gramedia, 2018. 